\title{
Evaluation Study Of Competencies Of Secondary School Teachers In Punjab In The Context Of Classroom Management
}

Safia Saeed, University of Wah, Pakistan

\begin{abstract}
There are so many characteristics and traits of personality and all the characteristics, qualities and competencies need training, grooming, improvement and development. The best classroom environment is one that results in efficient learning. Discipline involves employing guidance and teaching techniques to encourage students to become self-directive and therefore to create an atmosphere conducive to learning. Teachers are decision-makers as they manage the daily routines of their classrooms. Some teachers squeeze out every minute of learning possible. They are highly organized and well prepared, and they constantly think and plan ahead. This doesn't mean that they create a cold classroom atmosphere where students feel unwelcome. Rather, they are warm and enthusiastic teachers who are simply well organized and equally well versed in teaching. The major objective of this study was as to investigate the problems of classroom management of the secondary school teachers in Punjab. The population of the study consisted of the heads of the teacher training institutions, teacher educators, heads of secondary schools, secondary school teachers, and students. The sample included randomly selected ten heads of teacher training institutions, 50 teacher trainers, 800 hundred heads of secondary schools, 4,000 secondary school teachers and 4,000 students. Four questionnaires (one each for heads, teacher trainers, teachers and students) were developed for collection of data. Data were collected, analyzed and interpreted in the light of objective by using the Chi-Square. It was concluded from the study that the majority of respondents agreed that secondary school teachers were aware of time management skills, kept the classroom environment conducive for learning, and improved the learning skills of the students by using different behavior modification techniques. The majority of respondents agreed that secondary school teachers were dealing with the students in a nonpsychological way; it was the common areas in which secondary school teachers had weak competencies. For improving the classroom management skills, in-service short courses should be planned and attendance of secondary school teachers in such courses should be made obligatory. For maintaining the discipline in the class, teacher should be trained in such a way that they properly understand each and every method with its proper use in particular situations. Short courses, seminars and symposia should be organized on a regular basis to refresh the knowledge of working secondary teachers. Teachers should understand human, as well as educational, psychology and apply it in their teaching process in the classroom.
\end{abstract}

Keywords: competences, secondary school teachers, classroom management, learning, discipline, time

\section{INTRODUCTION}

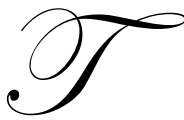

he quality of education is directly related to the quality of instruction in the classroom. The teacher is considered the most crucial factor in implementing all educational reforms at the grassroots level. It is a fact that the academic qualifications, knowledge of the subject matter, competence and skills of teaching, and the commitment of the teacher have effective impact on the teaching-learning process (Govt. of Pakistan, 1998). 
A student who spends more time pursuing academic content learns more and receives higher achievement scores. Researches have developed the following terms to allocate time, engaged time and academic learning time (Sadker and Sadker, 1997).

Successful classroom management has been defined as producing a high rate of work involvement with a low rate of deviancy in academic settings (Laslett and Smith, 1984).

Arranging the physical setting for teaching is a logical starting point for classroom management because it is a task that all teachers face before the school year begins. Many teachers find it easier to plan other aspects of the classroom after they have a clear idea of how the physical features of the classroom will be organized.

The following four keys are helpful for classroom management:

1. Keep high traffic areas free of congestion.

2. $\quad$ Be sure students can be seen easily by the teacher.

3. Keep frequently used teaching materials and student supplies readily accessible.

4. Be certain students can easily see whole-class presentations and displays (Evertson and Emmer, 2000).

The seating arrangement must depend on the type of lesson to be taught and the type of classroom furniture. The possession of a seating plan helps the teacher to learn names more rapidly (Laslett and Smith, 1984).

Desks, chairs and tables can be arranged in a variety of ways. Light and temperature can be increased and decreased. Painted wall coverings, artwork and plants can be used to enhance or detract from the attractiveness of the physical classroom environment (Anderson, 1991).

A teacher establishes classroom rules either with his or her students or before the school year begins. There is no research that one approach is better than the other. Rules are best if they are few in number, simple and easy to understand, and fair. Also, rules should be posted in the classroom for all to see and the teacher should go over the rules on the first day of school (Farris, 1996).

To some considerable degree, teachers control their instructional effectiveness in the classroom. The passive teacher simply relies on the same old teaching techniques day after day. However, the active teacher, who varies his/her day planning different teaching strategies and techniques, tends to achieve more success in teaching (Dhand, 1990).

According to Arif (2003), in order to create a classroom environment with maximum productive time utilization, the teachers must establish and maintain it through following teaching and managing practices.

1. Keeping the students motivated in learning, teachers set the stage for creating positive class environment.

2. Teachers must try to meet students' basic and age-related needs.

3. The degree of class control must be moderate.

4. Develop a set of few general classroom rules applicable in a variety of situations.

5. Keep instruction at the students' level.

6. Increase the 'engaged time' by keeping the students involved in the learning tasks.

Management in the classrooms and schools tended to focus on a reactive approach to dealing with problems as they arose. The teacher would concentrate on having stringent disciplinary measures in place. Students would be obedient because they were afraid of the consequences of misbehavior.

The following are management problems found in the classroom.

1. Difficult relationship with teachers

2. Irrelevance of curriculum

3. Family and community problems 
4. $\quad$ Failure of teachers to meet individual students' needs

5. Individual learning problems (Smith and Ewing, (2003)

The master teacher is conscious of individual differences and provides appropriate learning materials to meet these differences, utilizing various media of learning instead of limiting the class to reading and reciting. He appeals to the various senses of the students.

The seating arrangement enables everyone to communicate in a face-to-face manner rather than reciting only to the teacher. The expert teacher follows these practices because he has developed an understanding of adolescent growth and of how learning takes place (Gilchrist. et al.1985).

The psychological environment accounts for approximately 30 percent of the variance in cognitive, affective and behavioral outcomes beyond that accounted for by input measures, such as the entering ability or achievement of students (Walberg, 1987).

The objective of this study was to investigate the problems of classroom management of the secondary school teachers in Punjab.

The study is of great significance because it will provide workable guidelines to achieve the objectives of teacher education by suggesting improvements in the pre-service and in-service teacher education programs. This study will also be helpful to identify the personal and professional competencies of the teachers. It will provide guidelines for preparing norms for recruitment of teachers and will provide feedback to the curriculum developers in framing suitable curricula for teacher education programs. It will be helpful to improve the quality of education in schools and, in turn, the achievement of the objectives.

\section{PROCEDURE}

The major purpose of this study was to evaluate the competences of secondary school teachers in Punjab in the context of classroom management. The following procedure was adopted.

\section{SAMPLE}

Ten Universities and colleges of education and 40 secondary schools from each district were randomly selected. The target areas of the researcher were: Attock, Rawalpindi, Chakwal, Jhelum, Gujrat, Lahore, Sargodha, Faisalabad, Multan, Bahwalpur,Rahim Yar Khan, Bhawalnagar, Jhang, Okara, Toba Tek Sing, Mianwali, Sahiwal, Khanewal, Sialkot and Gujranwala. Ten universities and colleges of education, which provide teacher training, were randomly selected. From each district, the researcher selected 40 secondary schools, twenty from urban and twenty from rural areas.

Due to limited time and resources available with the researcher, the study was delimited to government, as well as semi-government, educational institutions in unjab. The institutions in the private sector were not included in the sample.

\section{INSTRUMENTS}

The researcher prepared the following four questionnaires in order to measure the teachers' competencies.

1. A questionnaire for heads of Teacher Training Institutions and teacher- trainers comprising 28 items.

2. A questionnaire for heads of secondary schools consisting of 50 items.

3. A questionnaire for Secondary school teachers having 50 items.

4. A questionnaire for students with 50 items.

For the statistical treatment of data, Chi Square was applied using the following formula: 


$$
\chi^{2} \quad=\quad \sum\left(\frac{\left(f_{o}-f_{e}\right)^{2}}{f_{e}}\right)
$$

\section{RESULTS AND DISCUSSION}

Table 1: Teachers come and leave the classroom in time.

\begin{tabular}{|l|c|c|c|c|c|c|c|}
\hline \multicolumn{1}{|c|}{ Category } & Highest & High & Moderate & Low & Lowest & Total & $\chi^{\mathbf{2}}$ \\
\hline Heads & 186 & 135 & 284 & 116 & 79 & 800 & $157.34^{*}$ \\
\hline Teachers & 778 & 1145 & 1385 & 647 & 45 & 4000 & $1318.96^{*}$ \\
\hline Students & 779 & 475 & 1443 & 1177 & 126 & 4000 & $1394.90^{*}$ \\
\hline
\end{tabular}

* Significant $\mathrm{df}=4 \chi^{2}$ (Table value) at 0.05 level $=9.488$

It is reflected from Table 1 that the $\chi^{2}$ value in all three cases was found greater than the table value at 0.05 level. Hence, the statement "Teachers come and leave the classroom in time" is accepted.

Table 2: Teachers come to the class well prepared.

\begin{tabular}{|l|c|c|c|c|c|c|c|}
\hline \multicolumn{1}{|c|}{ Category } & Highest & High & Moderate & Low & Lowest & Total & $\chi^{\mathbf{2}}$ \\
\hline Heads & 138 & 179 & 165 & 302 & 16 & 800 & $261.06^{*}$ \\
\hline Teachers & 1135 & 1070 & 1135 & 647 & 13 & 4000 & $1175.16^{*}$ \\
\hline Students & 1271 & 1419 & 1029 & 233 & 48 & 4000 & $1930.55^{*}$ \\
\hline
\end{tabular}

* $\quad$ Significant $\mathrm{df}=\chi^{2}$ (Table value) at 0.05 level $=9.488$

Table 2 depicts that the $\chi^{2}$ value in all three cases was found greater than the table value at 0.05 level. Hence, the statement "Teachers come to the class well prepared" is accepted.

Table 3: Teachers maintain discipline in the classroom.

\begin{tabular}{|l|c|c|c|c|c|c|c|}
\hline \multicolumn{1}{|c|}{ Category } & Highest & High & Moderate & Low & Lowest & Total & $\chi^{\mathbf{2}}$ \\
\hline Heads & 109 & 311 & 205 & 123 & 52 & 800 & $252.88^{*}$ \\
\hline Teachers & 1012 & 1458 & 1036 & 428 & 66 & 4000 & $1513.43^{*}$ \\
\hline Students & 1221 & 1389 & 783 & 575 & 32 & 4000 & $1456.13^{*}$ \\
\hline
\end{tabular}

* Significant $\mathrm{df}=4 \chi^{2}$ (Table value) at 0.05 level $=9.488$

Table 3 reflects that the $\chi^{2}$ value in all three cases was found greater than the table value at 0.05 level. Hence, the statement "Teachers maintain discipline in the classroom" is accepted.

Table 4: Teachers apply educational psychology in the classroom

\begin{tabular}{|l|c|c|c|c|c|c|c|}
\hline \multicolumn{1}{|c|}{ Category } & Highest & High & Moderate & Low & Lowest & Total & $\chi^{\mathbf{2}}$ \\
\hline Eads & 121 & 168 & 131 & 265 & 115 & 800 & $96.73^{*}$ \\
\hline Teachers & 118 & 797 & 1065 & 1012 & 1008 & 4000 & $779.46^{*}$ \\
\hline Students & 312 & 1198 & 321 & 1418 & 751 & 4000 & $1262.89^{*}$ \\
\hline
\end{tabular}

* Significant $\mathrm{df}=4 \chi^{2}$ (Table value) at 0.05 level $=9.488$

Table 4 indicats that the $\chi^{2}$ value in all three cases was found greater than the table value at 0.05 level. Hence, the statement "Teachers apply education psychology in the classroom" is accepted due to the value of Chi Square. Otherwise, the negative responses are more than the positive, which indicats that teachers did not apply educational psychology in the classroom. 


\section{DISCUSSION}

The results of the study indicate that all the respondents were of the view that the secondary school teachers came and left the classroom in time.

A teacher's function is not mere promotion of literacy by imparting a certain amount of knowledge to pupils. A teacher is the ideal model to be followed by students. He is a key to the whole education process. Successful teaching is linked to certain patterns of teaching behavior rather than specific personal characteristics or disciplinary methods. A teacher should be a person who commands the respect of pupils by virtue of what he is. So, the majority of respondents reported that secondary school teachers come to the class well prepared.

Another competency, which is more important for secondary school teachers, is classroom control. Sound classroom control is achieved most efficiently if the teacher is equipped with a theoretical and working knowledge of relevant principles that underlie classroom behavior - principles related to curriculum, planning, objectives and procedures, activity and experience, meaning and behavior, habits, growth and development, environmental influences, adolescent needs, expectations, readiness, and motivation.

In this way, they maintain the conducive environment of the classrooms for the improvement of learning skills of the students. This skill not only maintains the discipline in the classroom, but also makes teaching an interesting activity. So the majority of respondents reported that secondary school teachers maintain the discipline in the classroom.

The majority of all categories of respondents agreed that secondary school teachers did not treat the students in a psychological way. The reason may be the lack of knowledge of the secondary school teachers in the area of child psychology. This may be attributed to the weak programme of teacher training where the prospective teachers are not practically trained in dealing with the students in a psychological way. If they were fully trained in child psychology they would have developed and utilized this competency in the proper way.

\section{CONCLUSIONS}

On the basis of analysis of data, the following conclusions were drawn:

A vast majority of heads of teacher training institutions, teacher trainers, heads of secondary schools, secondary school teachers, and students accepted that secondary school teachers came and left the classroom in time.

On the basis of results, all categories of respondents reported that secondary school teachers maintain discipline in the class to improve the learning skills of the students by using different behaviour modification techniques.

The teacher used his/her best professional judgment to decide which method; strategy and techniques work best for a particular situation.

The best classroom environment is one that results in efficient learning. If teachers come to the class well prepared, it encourages students to become self-directive, thus creating an atmosphere conducive for learning.

Therefore, the majority of respondents agreed that secondary school teachers come to the class well prepared.

The majority of the heads of secondary schools, heads of teacher training institutions, secondary school teachers, and the students, agreed that secondary school teachers deal with students in a non-psychological way. Perhaps teachers did not understand child psychology and were unaware of the problems of students that may occur due to lack of training in this area and poor knowledge in child psychology that demands proper training in these areas. 


\section{AUTHOR INFORMATION}

Dr Safia Saeed obtained a (B.A) Bachelor of Arts degree from the University of Punjab Lahore (Pakistan) in 1999 having Education as Elective subject, a Master of Science Education in the year 2002 and a Doctor of Philosophy in Education from UAAR (University of Arid Agriculture Rawalpindi) in the year 2005. He has now been serving as an Assistance Professor in the Department of Education University of Wah, Wah Cantt (Pakistan). His areas of interest are, Teacher Education, Educational System, Curriculum Development, Educational Research, Planning and Management. This article is written in the light of "An Evaluation Study of Competencies of Secondary School Teacher in Punjab in Context of Classroom Management".

\section{REFERENCES}

1. Anderson, W. L. (1991) Increasing Teacher Effectiveness. Paris: UNESCO: International Institute for Educational Planning, P.16, 18.

2. Arif, H. M.( 2003) Human Development and Learning. Lahore, Pakistan: Majeed Book Depot. PP.107-190.

3. Callahan, S. G. (1966) Successful Teaching in Secondary Schools. Atlanta: Foresman and Company .PP.111-313.

4. Dhand, H. (1990). Techniques of Teaching. New Dehli, India: Shish Publishing House. PP.1-3.

5. $\quad$ Evertson, M. C. ,E.T.Emmer and M. E. Worsham(2000) USA, Allyn and Bacon. P 1-3.

6. Farris, G. P. (1996) Teaching: Bearing the Torch. London, UK: Brown and Benchmark.PP.218-243.

7. Gilchrist, S. R., W. H. Dutton and W. L. Wrinkle ( 1985) Secondary Education for American Democracy. New York, USA: Rinehart and Company Inc,.PP.94-316.

8. Govt. of Pakistan (1998) National Education Policy 1998-2010. Islamabad, Pakistan: Ministry of Education. P.47.

9. Laslett R.and C. Smith(1984) Effective Classroom Management: A Teacher's Guide. London, UK: Croon Helm Ltd,. PP.1-10.

10. Sadker, P. M. and D. M. Sadker( 1997) Teachers School and Society. New York, USA: The McGraw-Hill Companies, Inc. PP.39- 66.

11. Smith, G.S., R. Ewing, and R.L.CORNU (2003) Hustralia, Harcourt.P.245.250.

12. Walberg,J.H.(1987) Psychological Environment. The International Encyclopedia of teaching and teacher Education, Oxford, London, UK: Pergamon Press. P.353. 